\title{
Does Trans-Stimulation of L-Tyrosine Lead to an Increase in Boron Uptake in Head and Neck Squamous Cell Carcinoma Cells?
}

\author{
Matthias Gielisch (D), Maximilian Moergel, Bilal Al-Nawas (D) and Peer W. Kämmerer *(D) \\ Department of Oral- and Maxillofacial Surgery, University Medical Center Mainz, 55131 Mainz, Germany; \\ matthias.gielisch@unimedizin-mainz.de (M.G.); maximilian.moergel@unimedizin-mainz.de (M.M.); \\ bilal.al-nawas@unimedizin-mainz.de (B.A.-N.) \\ * Correspondence: peer.kaemmerer@unimedizin-mainz.de
}

Citation: Gielisch, M.; Moergel, M.; Al-Nawas, B.; Kämmerer, P.W. Does Trans-Stimulation of L-Tyrosine Lead to an Increase in Boron Uptake in Head and Neck Squamous Cell Carcinoma Cells? Appl. Sci. 2021, 11, 7286. https://doi.org/10.3390/ app11167286

Academic Editor: Roger Narayan

Received: 2 July 2021

Accepted: 6 August 2021

Published: 8 August 2021

Publisher's Note: MDPI stays neutral with regard to jurisdictional claims in published maps and institutional affiliations.

Copyright: (c) 2021 by the authors. Licensee MDPI, Basel, Switzerland. This article is an open access article distributed under the terms and conditions of the Creative Commons Attribution (CC BY) license (https:// creativecommons.org/licenses/by/ $4.0 /)$.

\begin{abstract}
Background: For advanced head and neck squamous cell carcinoma (HNSCC), boron neutron capture therapy (BNCT) is a potential therapeutic option, but high concentrations of boron within HNSCC are necessary. Therefore, this in vitro pilot study examined the uptake and concentration of boron in HNSCC cells using the trans-stimulation effect of L-tyrosine when compared to non-stimulated samples. (2) Methods: Two HNSCC cell lines were incubated with L-tyrosine for up to two hours, followed by incubation with three L-para-boronophenylalanine (BPA) concentrations $(5,20,50 \mathrm{ppm})$ at eight incubation times (1-4.5 h in half-hour steps). Subsequently, cellular boron uptake was measured via inductively coupled plasma mass spectrometry. (3) Results: No differences between laryngeal and oral SCC cells were seen; therefore, data were pooled. In total, boron uptake was not significantly increased in trans-stimulated samples when compared to the control group (all $p>0.05$ ). Nevertheless, with trans-stimulation, higher BPA concentrations resulted in higher intracellular boron concentrations $(5<20<50$ ppm; all: $p<0.05)$, whereas these differences were less distinct in the non-trans-stimulated group. (4) Conclusions: The effect of trans-stimulation for up to two hours seems to be less relevant for HNSCC, though trans-stimulated HNSCC cells seem to have a more distinct BPA-dose-dependent cellular boron uptake that might be addressed in further research.
\end{abstract}

Keywords: boron neutron capture therapy; trans-stimulation; head and neck cancer; squamous cell carcinoma; preloading

\section{Introduction}

Head and neck cancer-with about $90 \%$ squamous cell carcinoma (HNSCC) — accounts for $3 \%$ of all cancer types, with an incidence of about 900,000 new cases and 500,000 deaths per year [1]. Treatment, independent of stage, includes surgery, radiation and additional chemotherapy. However, for advanced as well as metastatic HNSCC, additional treatment options are needed. One of these therapies could be boron neutron capture therapy (BNCT), which is based on the reaction of the non-radioactive boron-10 with low-energy (thermal) neutrons, resulting in the nuclear reaction ${ }^{10} \mathrm{~B}(\mathrm{n}, \alpha){ }^{7} \mathrm{Li}$. Because of the short range of the produced alpha particles and lithium from about 8-10 $\mu \mathrm{m}$ with a high linear energy transfer, the radiation effects mainly occur in cells containing boron [2]. To treat a tumour with $\mathrm{BNCT}$, it is necessary to reach a high concentration of boron in tumour cells, especially in comparison to normal tissue. Second, the tumour should not be seated more than 6-8 cm under the skin, otherwise-due to its poor penetration-the thermal neutron beam cannot reach the tumour [3]. In practice, a boron carrier such as mercaptoundecahydrocloso-dodecaborate (BSH) or L-para-boronophenylalanine (BPA), a modified amino acid, is infused in a fructose solution into a peripheral vein, resulting in a higher uptake of the ${ }^{10} \mathrm{~B}$ carrier in cancerous tissue as tumour cells have a higher turnover with an increased energy consumption $[4,5]$. The L-system transports amino acids with heavy side chains such as 
tyrosine or phenylalanine [6]. Because of the similarity of BPA and phenylalanine, this transport system was identified as important for BPA uptake [7]. In the oral mucosa, LAT-1 is located in the basal cell layer, and is both intracellular and membrane-bound. Whereas the expression of LAT-1 in normal mucosa is low [8], it increases in cases of HNSCC and decreases for the highest dedifferentiation levels [9].

HNSCC is stated as a suitable target for BPA-mediated BNCT with a tumour/tongue ${ }^{10} \mathrm{~B}$ ratio of up to 4.1 [10] and a high rate of patients that respond to BNCT treatment, even with inoperable, locally recurrent and previously irradiated cancer [5]. Various approaches for enhancement of BPA uptake in carcinoma cells have been proposed, such as pre-treatments with low-dose gamma irradiation before or during BPA incubation [11] and pulsed focused ultrasound [12]. Different infusion methods for BPA such as intravenous, intra-arterial or direct infusion into the carotid artery in the case of brain tumours were studied as well [13]. Another way to increase boron uptake is based on the transport mechanism of amino acids that aims to reach an equilibrium between efflux and influx. In this regard, two relevant phenomena are described: cis-inhibition and trans-stimulation. Cis-inhibition, as seen in erythrocytes [14], inhibits productive signals, whereas transstimulation indicates an exchange of intracellular for extracellular amino acids via the L-system $[15,16]$. Trans-stimulation effects are described for various cell lines. For example, gliosarcoma cells showed an increased BPA accumulation after incubation with L-tyrosine, whereas simultaneous incubation of BPA and L-tyrosine led to a decrease in boron uptake [17]. In a xenograft tumour model, preloading with L-phenylalanine reduced the boron uptake in brain tissues relative to the uptake in the tumour tissue, and therefore reduced the maximum irradiation dose in normal tissue [18]. Further in vitro and in vivo investigations showed that preloading with L-tyrosine as well was with L-DOPA before exposure to BPA increased the intracellular boron concentration by a factor of three, while normal tissue did not show an increased BPA uptake $[17,19,20]$.

The aim of the present study was an evaluation of the potential increase in the uptake of BPA into HNSCC cell lines utilising trans-stimulation with L-tyrosine, which seems to be clinically feasible. The null hypothesis was that trans-stimulation with L-tyrosine does not enhance the uptake of boron in HNSCC cells after BPA incubation.

\section{Materials and Methods}

\subsection{Cell Culture}

Two different head and neck squamous cell carcinoma (HNSCC) cell lines were used. Here, PCI 1 was cultured from a 65-year-old, male patient with a moderately differentiated, recurrent squamous cell carcinoma of the larynx with unknown TNM classification, whereas PCI 13 was cultured from a 50-year-old, male patient with a badly differentiated, recurrent squamous cell carcinoma of the trigonum retromolare with the following TNM classification: T3 N1 M0 [21]. Human oral keratinocytes (HOK, \#2610, ScienCell, Carlsbad, CA, USA) and pooled human gingival epithelial cells (pHGEP; CELLnTEC, Bern, Switzerland) were used as a controls for immunoblotting.

Cell lines were cultured in Dulbecco's modified Eagle medium (DMEM; SigmaAldrich, St. Louis, MO, USA) supplemented with 10\% foetal calf serum (GE Healthcare Life Sciences, Little Chalfont, UK), streptomycin and penicillin (GE Healthcare Life Sciences, Little Chalfont, UK) in culture flasks ( $250 \mathrm{~mL}$, Greiner bioone, Kremsmünster, Austria) or cultures dishes ( $\mathrm{d}=100 \mathrm{~mm}$, BD Biosciences, Franklin Lakes, NJ, USA). The incubator (Heraeus Instruments, Hanau, Deutschland) was set to humidified air containing $5 \% \mathrm{CO}_{2}$ at $37^{\circ} \mathrm{C}$. Cells were passaged in their log phase, approximately every $2-3$ days.

\subsection{Western Blot}

Cells (PCI 1, PCI 13, HOK and pHGEP,) were cultured as described above in Petri dishes until approximately $80 \%$ confluence was reached. The following steps were conducted on ice: Cells were rinsed with cold phosphate-buffered saline (PBS) two times. Subsequently, cells were incubated with $500 \mu \mathrm{L}$ radioimmunoprecipitation-buffer (RIPA 
Buffer, R0278, Sigma-Aldrich, St. Louis, MO, USA), $50 \mu \mathrm{L}$ protease-inhibition cocktail and $10 \mu \mathrm{L}$ phosphatase-inhibition cocktail for $5 \mathrm{~min}$. After mechanical release, protein concentrations were determined with a Pierce ${ }^{\circledR}$ BCA protein assay kit (REF: 23227, ThermoSCIENTIFIC, Waltham, MA, USA) according to the manufacturer's protocol. Finally, suspensions with $15 \mu \mathrm{g}$ protein were used for separation in a Mini-PROTEAN ${ }^{\circledR}$ Tetra Cell (bio-rad Laboratories, Pleasanton, CA, USA) with a Mini-PROTEAN ${ }^{\circledR}$ TGX ${ }^{\circledR}$ Gel (\#4561094, bio-rad Laboratories). The samples were blotted on a PVDF membrane (IPVH00010, Immobilon ${ }^{\circledR}$-P transfer membrane, Merck, Darmstadt, Germany). After blocking for $1 \mathrm{~h}$, incubation with the primary antibody (\#5347S, rabbit anti-LAT1 antibody, 1:1000, Cell Signaling Technology, Danvers, MA, USA) and Tris-buffered saline (TBS, Sigma-Aldrich) for $24 \mathrm{~h}$ took place. After washing three times with TBS-W (Sigma-Aldrich) for $15 \mathrm{~min}$, the secondary HRP-linked antibody (\#7074S, IgG anti-rabbit antibody, 1:1000, Cell Signaling Technology) was added for $1 \mathrm{~h}$. Subsequently, the membrane was washed three times with TBS-W (Sigma-Aldrich) for $10 \mathrm{~min}$. Enhanced luminol-based chemiluminescent (RPN2232, Amersham $^{\mathrm{TM}}$, GE Healthcare Life Sciences, Little Chalfont, UK) was used for the detection of the horseradish peroxidase on the membrane. Analysis was conducted using the Western blot imaging system Fusion Solo S (Vilber Lourmat, Collégien, France).

\subsection{Trans-Stimulation Experiments}

As L-tyrosine and L-phenylalanine use the same (LAT-1) transport system, the decision to use L-tyrosine for these experiments was based on the results from other cell lines and trans-stimulation from other groups [19].

After $48 \mathrm{~h}$ of cultivation, medium was removed and cells were washed twice with phosphate-buffered saline (PBS) at $37^{\circ} \mathrm{C}$. Groups with one or two hours of trans-stimulation were incubated in a $5 \mathrm{mmol}$ L-tyrosine solution. Here, a $50 \mathrm{mmol}$ L-tyrosine stock-solution was prepared by stirring $180 \mathrm{mg}$ L-tyrosine (Sigma-Aldrich, St. Louis, MO, USA) after filling it up to $20 \mathrm{~g}$ with Aqua Dest. After sterile filtration with a Whatman filter FP 30/0-2 CA-S (GE Healthcare Life Sciences, Little Chalfont, UK), the stock solution was diluted 10-fold with Hank's balanced salt solution (HBSS, Invitrogen Lifescience, Carlsbad, CA, USA). Incubation with L-tyrosine for trans-stimulation was conducted by removing the medium from cells after $48 \mathrm{~h}$ and rinsing two times with PBS at $37^{\circ} \mathrm{C}$. Afterwards, $2 \mathrm{~mL}$ of $5 \mathrm{mmol}$ L-tyrosine solution was added to every dish and incubated for one or two hours in the incubator. Then, cells were covered with $2 \mathrm{~mL}$ of 5, 20 and $50 \mathrm{ppm}$ BPA-solution (Katchem, Prague, Czech Republic) for 1, 1.5, 2, 2.5, 3, 3.5, 4 and 4.5 h (Figure 1). BPA solutions were produced by diluting a 500 ppm stock solution with HBSS.

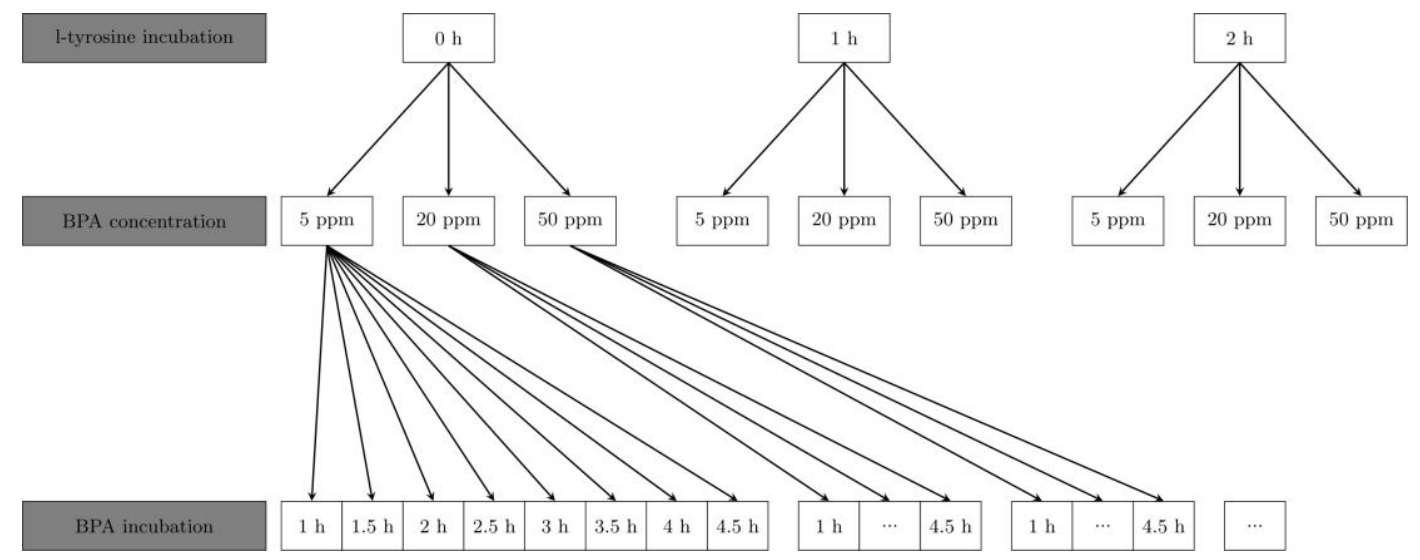

Figure 1. Flowchart of the different groups of L-tyrosine incubation times, used BPA concentrations and BPA incubation times; ppm = parts per million. 


\subsection{Boron Analysis}

Acidic digestion for boron analysis was carried out using an inductively coupled plasma mass spectrometer (ICP-MS). The cell samples were prepared by adding $1 \mathrm{~mL}$ $\mathrm{HNO}_{3}$ and $1 \mathrm{~mL} \mathrm{H}_{2} \mathrm{O}_{2}$, followed by incubation on a vibrating plate. Afterwards, $1 \mathrm{~mL}$ of this solution was mixed with $1 \mathrm{~mL} \mathrm{NH}_{3}, 2.9 \mathrm{~mL}$ of a solution containing $2 \%$ butanol, $1 \% \mathrm{NH}_{3}, 0.05 \%$ EDTA and $0.05 \%$ Triton-X 100 (all from Sigma-Aldrich, Munich, Germany), 0.05 mL Rhodium Standard (1 ppm, High Purity Standards, North Charleston, SC, USA) and Beryllium Standard (10 ppm, High Purity Standards, North Charleston, SC, USA). Beryllium solution and rhodium solution were used as internal standards. For quantification, a calibration curve with BPA solutions were created. Finally, ICP-MS (Agilent 7500ce series (Santa Clara, CA, USA) was carried out in order to determine the intracellular boron content (for each group, at least $\mathrm{n}=3$ ).

\subsection{Statistics}

Data were collected with Microsoft Excel (Version 2013, Microsoft, Redmond, DC, USA) and statistics were carried out with RStudio (Version 1.2.1335, Integrated Development for R. RStudio, Inc., Boston, MA, USA) and R (Version 3.6.0, R Foundation for Statistical Computing, Vienna, Austria). Figures were created with R package ggplot2 (Version 3.2.1). Mean and standard deviations were calculated. Data from different cell lines, PCI 1 and PCI 13, and the two L-tyrosine incubation times, one and two hours, were analysed separately and in combination (pooled). Moreover, a multifactor analysis of variance (ANOVA) with a post hoc Games-Howell test was performed. Levene test for variance homogeneity was significant. Therefore, the following presented statistical results were considered to be descriptive. $p<0.05$ was considered significant.

The control group was the non-trans-stimulated group, and the trans-stimulated group was defined as the treatment group. Independent variables were trans-stimulation with two factors, trans-stimulated versus non-trans-stimulated, BPA concentration with three factors, 5, 20 and $50 \mathrm{ppm}$, and BPA incubation time with eight factors. The dependent variable was the measured boron uptake.

\section{Results}

\subsection{Western Blotting of LAT-1 in PCI 1 and PCI 13 Cell Lines}

The expression of LAT- 1 in PCI 1 and PCI 13 cell lines was confirmed by Western blotting (Figure 2). It can be seen that the amount of LAT-1 for healthy oral cells such as HOK and pHGEP is lower than for those of the tumour cell lines PCI 1 and PCI 13. Furthermore, the PCI 13 cell line showed a higher expression of LAT-1 when compared to PCI 1.

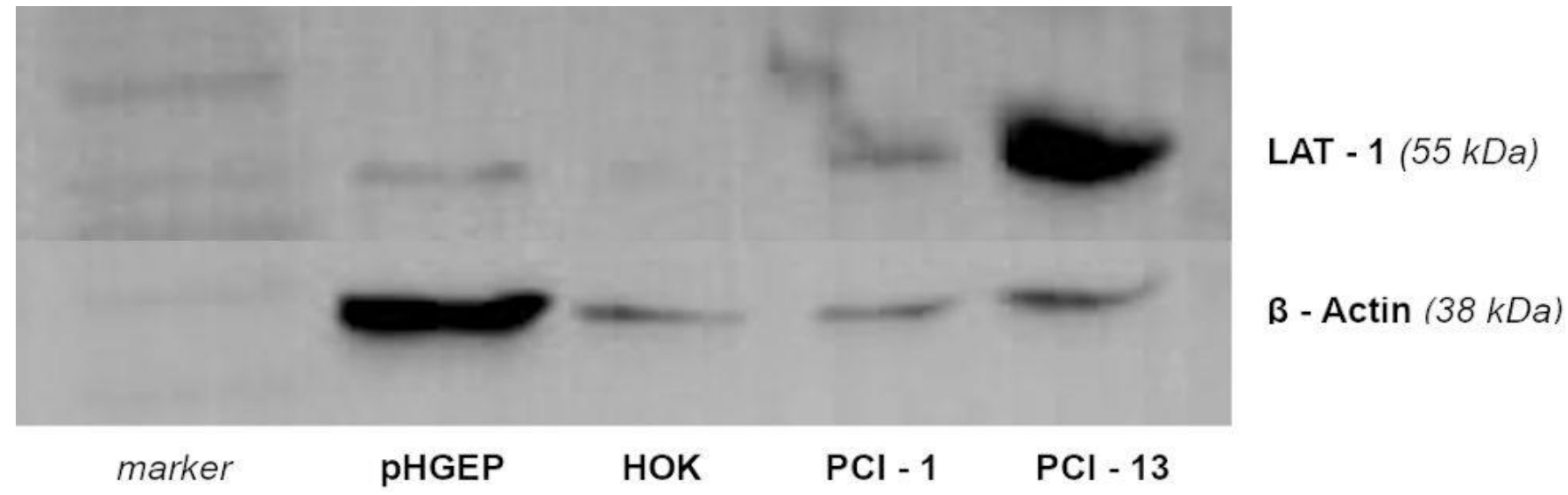

Figure 2. Results of Western blot for proteins from PCI 1 and PCI 13. LAT-1 is detectable for both cell lines at $38 \mathrm{kDa}$. Human oral keratinocytes (HOK) and pooled human gingival epithelial cells (pHGEP) were used as control. The expression is clearly higher in PCI 1 and PCI 13 when compared to controls. 


\subsection{Boron Uptake in OSCC Cell Lines in Association with Trans-Stimulation}

As there were no statistically relevant differences when analysing the cell lines separately (all $p>0.01$ ), the data of the two lines were pooled and described accordingly. The boron uptake depending on trans-stimulation and used BPA concentrations are shown in Figure 3.

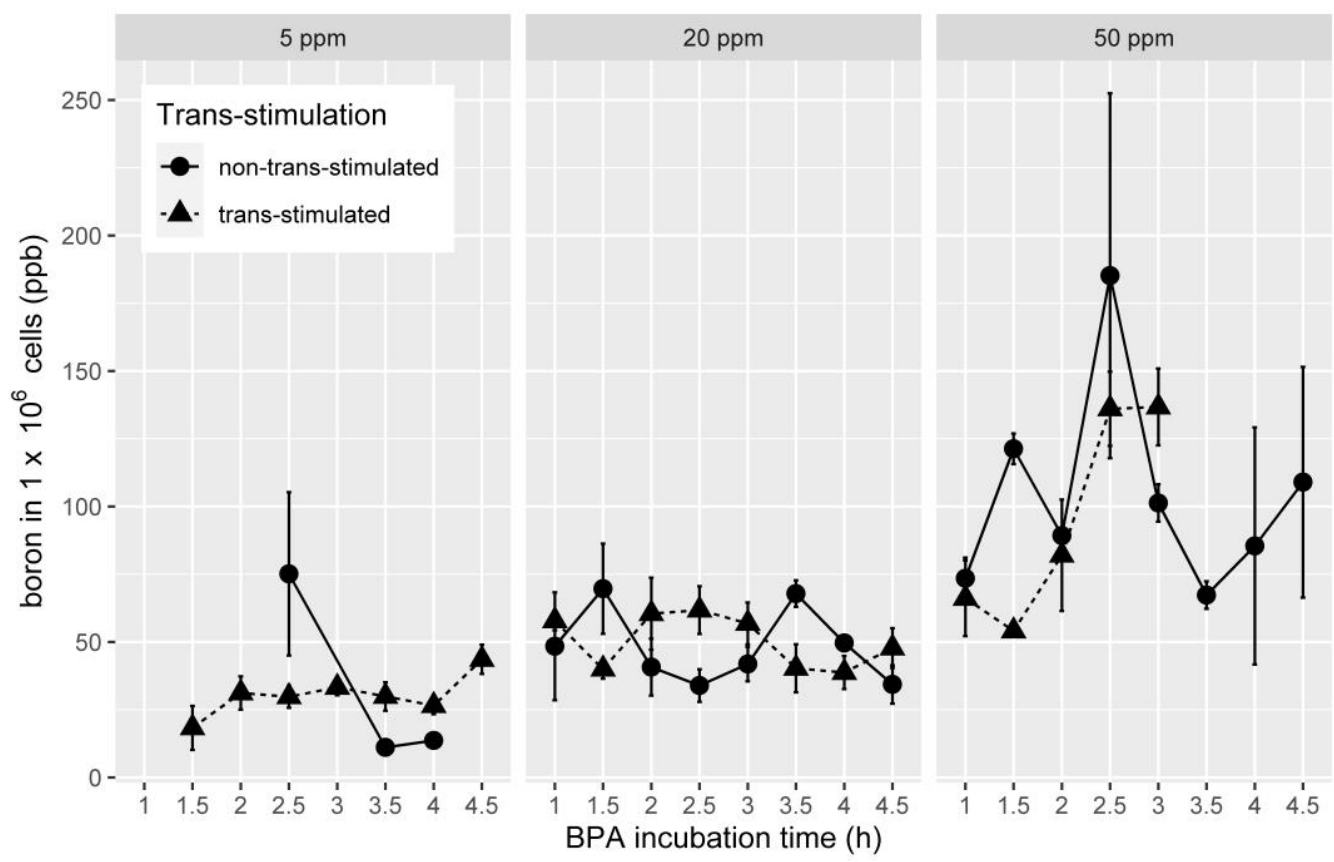

Figure 3. Line charts with error bars for standard error (SE) indicating boron content independent of BPA concentration $(5,20$ and $50 \mathrm{ppm})$ and BPA incubation time (ppb = parts per billion, circles indicate non-trans-stimulated and triangles trans-stimulated cells).

In brief, no significant differences between both groups with the same BPA concentrations at the same time points were seen (all: $p>0.05$, Table 1 ).

Table 1. Results of the ANOVA—no significant effect for trans-stimulation was seen.

\begin{tabular}{ccccc}
\hline $\begin{array}{c}\text { BPA Concentration } \\
(\text { ppm) }\end{array}$ & Trans-Stimulation & $\begin{array}{c}\text { Mean Boron Concentration } \\
\text { (ppb per One Million Cells) }\end{array}$ & SD & $\boldsymbol{p}$ \\
\hline \multirow{2}{*}{5} & no & 50.31600 & 63.72422 & \\
& yes & 29.25684 & 13.29931 & \\
20 & no & 48.92545 & 30.77410 & 0.893 \\
& yes & 51.18492 & 26.31162 & \\
\multirow{2}{*}{50} & no & 98.63308 & 49.07148 & 0.998 \\
& yes & 82.42652 & 43.24766 & 0.615 \\
\hline
\end{tabular}

For $5 \mathrm{ppm}$ BPA concentration, the maximum boron content showed up after $2.5 \mathrm{~h}$ with $75.16 \mathrm{ppb}$ per one million. For cells without trans-stimulation, the mean uptake for all time points was 50.32 (standard deviation (SD): \pm 63.72 ) ppb per one million cells. Transstimulated cells reached $43.60 \mathrm{ppb}$ per one million cells after $4.5 \mathrm{~h}$ with a mean uptake of 29.27 (SD: \pm 13.30$)$ ppb per one million cells for all time points. Incubation with a BPA concentration of $20 \mathrm{ppm}$ resulted in the highest boron content $(69.65 \mathrm{ppb}$ per one million cells) in the non-trans-stimulated group after $1.5 \mathrm{~h}$. With trans-stimulation, the highest boron content (61.78 ppb per one million cells) was seen after $2.5 \mathrm{~h}$ of BPA incubation. The mean uptake for all BPA incubation times with $20 \mathrm{ppm}$ without trans-stimulation reached 48.93 (SD: \pm 30.77 ) ppb per one million cells and 51.18 (SD: \pm 26.31 ) ppb per one million cells with trans-stimulation. Regarding incubation with a BPA concentration of 
$50 \mathrm{ppm}$, the maximum was reached without trans-stimulation after $2.5 \mathrm{~h}$ (124.64 ppb per one million cells), whereas the mean uptake for all time points was 113.05 (SD: \pm 89.05$) \mathrm{ppb}$ per one million cells. In the trans-stimulated cells group, the highest boron uptake was detected after $3 \mathrm{~h}$ (136.74 ppb per one million cells) with a mean of 82.43 (SD: \pm 43.25$) \mathrm{ppb}$ per one million cells for all time points.

\subsection{Boron Uptake in HNSCC Cell Lines in Association with BPA Concentration}

With trans-stimulation, boron uptake between the various groups of BPA concentrations differed significantly, namely 20 vs. $50 \mathrm{ppm}(p<0.032$, Table 2$), 20$ vs. $5 \mathrm{ppm}(p<0.001$, Table 2$)$ and 50 vs. 5 ppm $(p<0.001$, Table 2). According to this, higher BPA concentrations resulted in higher intracellular boron concentrations. Without trans-stimulation, only the boron uptake in the group with a BPA incubation of $50 \mathrm{ppm}$ was significantly higher in comparison with the boron uptake in the non-trans-stimulated 20 ppm group $(p<0.012$, Table 2).

Table 2. Results of the Games-Howell post hoc test-significant differences were detected within the trans-stimulated groups.

\begin{tabular}{|c|c|c|c|c|c|c|}
\hline \multirow[b]{2}{*}{ Trans-Stimulation } & \multirow{2}{*}{$\begin{array}{l}\text { BPA Concentration } \\
(\mathrm{ppm})\end{array}$} & \multirow{2}{*}{$\begin{array}{l}\text { Mean Boron Concentration } \\
\text { (ppb per One Million Cells) }\end{array}$} & \multirow[b]{2}{*}{ SD } & \multicolumn{3}{|c|}{$p$} \\
\hline & & & & $\begin{array}{l}5 \text { ppm vs. } \\
20 \text { ppm }\end{array}$ & $\begin{array}{l}5 \text { ppm vs. } \\
50 \text { ppm }\end{array}$ & $\begin{array}{l}20 \text { ppm vs. } \\
50 \text { ppm }\end{array}$ \\
\hline \multirow{3}{*}{ no } & 5 & 50.31600 & 63.72422 & \multirow{3}{*}{1.000} & \multirow{3}{*}{0.208} & \multirow[b]{3}{*}{0.012} \\
\hline & 20 & 29.25684 & 13.29931 & & & \\
\hline & 50 & 48.92545 & 30.77410 & & & \\
\hline \multirow{3}{*}{ yes } & 5 & 51.18492 & 26.31162 & \multirow{3}{*}{0.000} & \multirow{3}{*}{0.000} & \multirow{3}{*}{0.032} \\
\hline & 20 & 98.63308 & 49.07148 & & & \\
\hline & 50 & 82.42652 & 43.24766 & & & \\
\hline
\end{tabular}

\section{Discussion}

For BNCT, a high concentration of boron within the cancer cells is mandatory as, theoretically, only those cells will be destroyed after neuron irradiation, leaving surrounding normal cells undamaged. However, even if trans-stimulation seems to increase boron uptake in HNSCC cells with increasing BPA concentrations, no distinct effect of transstimulation for the uptake of boron in HNSCC cells after BPA incubation in comparison to non-stimulated cells could be shown.

For HNSCC, adjuvant radiation therapy and/or chemotherapy are recommended for advanced stages. Known adverse effects of radiation such as pain and xerostomia have a negative impact on speech, chewing and swallowing [22]. BNCT might reduce these side effects because of its principle to target tumour cells. Here, one major concern is that boron uptake in tumour cells has to be increased, as reported disadvantages of BNCT include inhomogeneous BPA distribution in the tumour and an insufficient coverage of the clinical target volume [23]. The expression of LAT-1, which is proposed to be one of the most relevant amino acid transporters for BPA uptake, increases from normal to precursor lesions to tumour tissue, but seems to decrease for higher dedifferentiation levels of HNSCC [9]. Therefore, the HNSCC cell lines used in the present study are described as moderately and badly differentiated [21] and the presence of LAT-1 in both HNSCC cell lines was confirmed by Western blotting.

The BPA uptake of HNSCC cells in this analysis was 1.10 times higher after transstimulation with a BPA concentration of $50 \mathrm{ppm}$ when compared to the non-trans-stimulated samples, but without a significant difference. In the literature, the boron content of B16F1 melanoma cells was increased after trans-stimulation to 1.8-2.7 times higher [19] and in GS9L gliosarcoma cells to approximately two times higher [17]. A reason for the non-existent effect of trans-stimulation in HNSCC cells could be the dedifferentiation of the tumour cells, which leads to a lower LAT-1 expression [9]. Overall, beneath the trans-stimulation effect, it is also possible that the lack of leucin, an amino acid similar to BPA, leads to an activation of system L [24,25]. Subsequently, the observed minor increase in boron content 
could be justified by this activation, because the trans-stimulation medium was free of amino acids except L-tyrosine.

It is also remarkable that the overexpression of system L transporter LAT-1 in different cells such as hepatocytes and fibroblasts did lead to increased leucin uptake in hepatocytes but not in fibroblasts [26]. It appears likely that miscellaneous cell lines with their proteomes show different uptake behaviour. For example, in human hepatocellular carcinoma cells, no trans-stimulation effect was seen [27]. Likewise, melanoma cells showed no significantly increased boron content after trans-stimulation, and a lower boron uptake after $90 \mathrm{~min}$ of trans-stimulation was observed for adenocarcinoma cells and human hepatocellular carcinoma cells [28]. Most commonly, the concentration of the used L-tryrosine solution was $5 \mathrm{mmol} / \mathrm{L}$, as this concentration is known to be non-toxic in vitro. Therefore, this concentration was used in the present analysis as well. However, a solution with $2.5 \mathrm{mmol}$ seems to improve the boron uptake after trans-stimulation in certain cell lines [28].

Research using longer trans-stimulation times with L-DOPA for rat glioma cells achieved the strongest trans-stimulation effect after $4 \mathrm{~h}$, whereas a small increase in the resulting BPA concentration was seen after two hours of stimulation [20]. Another investigation with shorter trans-stimulation times up to $90 \mathrm{~min}$ indicated a decrease in the measured boron uptake after $1 \mathrm{~h}$ for some cell lines, whereas for others the uptake did not change between 60 and $90 \mathrm{~min}$ [28]. Since this seemed to be a critical time period, the effect of up to two hours of incubation time with L-tyrosine was investigated in the present study without detecting significant differences. However, longer incubation times of up to $4 \mathrm{~h}$, as demonstrated by Yang et al. for glioblastoma and melanoma cells [13], might have resulted in higher BPA concentrations, even if this effect was not seen by the same group in vivo.

The timepoint of the highest boron increase without trans-stimulation was seen in the time between 1.5 and $2.5 \mathrm{~h}$ and is analogous to the results described in the literature $[10,29]$. A significantly higher boron uptake without trans-stimulation was reached by administration of high BPA concentrations ( 20 vs. 50 ppm, $p<0.012$ ). Healthy tissues such as skin also show a higher boron uptake depending on the BPA concentration. In lung cancer metastasis [30] and HNSCC in a hamster cheek pouch model [29], a higher BPA concentration resulted in higher boron uptake. Interestingly, the use of L-tyrosine led to significant differences between the three BPA concentration groups ( 5 vs. 20 vs. $50 \mathrm{ppm}$ ). The effect between the 5 and $20 \mathrm{ppm}$ groups seems to arise from a lower boron uptake in the $5 \mathrm{ppm}$ group. Besides the effect of trans-stimulation, another effect, called trans-inhibition, was described as a negative feedback regulation [31]. It is supposed that the mechanism behind this effect relies on a slowing of entry by a high intracellular content, i.e., of an analogue of the solute (in this case L-tyrosine). The observed lower boron uptake could be the result of this effect. Hence, the use of L-tyrosine in combination with low BPA concentrations could be counterproductive for an increase in boron uptake. Future research might need to focus on boron uptake when comparing more than one cell line that is moderately differentiated with more than one cell line that is weakly differentiated.

\section{Conclusions}

The combination of trans-stimulation and an increased BPA dose seem to have a relevant effect on boron uptake by HNSCC cells. As a consequence, the efficiency of BNCT to treat recurrent or enlarged NHSCC could be enhanced via selective enrichment of boron in tumour cells, even if the tumour and the normal cells are mingled at the tumour margin. Even so, the effect of trans-stimulation for up to two hours seems to be less relevant for moderately to badly differentiated HNSCC, and might not be a sufficient method for boron enrichment in those tumour entities. 
Author Contributions: Conceptualisation, M.G., B.A.-N., M.M. and P.W.K.; methodology, M.G., B.A.-N. and M.M.; validation, M.G., B.A.-N. and M.M.; formal analysis, M.G., B.A.-N., P.W.K. and M.M.; investigation, M.G.; resources, B.A.-N.; data curation, M.G.; writing-original draft preparation, M.G. and P.W.K.; writing-review and editing, M.G. and P.W.K.; visualisation, M.G. and P.W.K.; supervision, M.M. and B.A.-N.; project administration, M.M. and B.A.-N.; funding acquisition, M.G. All authors have read and agreed to the published version of the manuscript.

Funding: This research received no external funding.

Institutional Review Board Statement: Not applicable.

Informed Consent Statement: Not applicable.

Data Availability Statement: The data presented in this study are available on request from the corresponding author.

Conflicts of Interest: The authors declare no conflict of interest.

\section{References}

1. Muzaffar, J.; Bari, S.; Kirtane, K.; Chung, C. Recent Advances and Future Directions in Clinical Management of Head and Neck Squamous Cell Carcinoma. Cancers 2021, 13, 338. [CrossRef] [PubMed]

2. Barth, R.F.; Vicente, M.H.; Harling, O.K.; Kiger, W.S., 3rd; Riley, K.J.; Binns, P.J.; Wagner, F.M.; Suzuki, M.; Aihara, T.; Kato, I.; et al. Current status of boron neutron capture therapy of high grade gliomas and recurrent head and neck cancer. Radiat. Oncol. 2012, 7, 146. [CrossRef]

3. Suzuki, M. Boron neutron capture therapy (BNCT): A unique role in radiotherapy with a view to entering the accelerator-based BNCT era. Int. J. Clin. Oncol. 2020, 25, 43-50. [CrossRef] [PubMed]

4. Christensen, H.N. Role of amino acid transport and countertransport in nutrition and metabolism. Physiol. Rev. 1990, 70, 43-77. [CrossRef]

5. Koivunoro, H.; Kankaanranta, L.; Seppälä, T.; Haapaniemi, A.; Mäkitie, A.; Joensuu, H. Boron neutron capture therapy for locally recurrent head and neck squamous cell carcinoma: An analysis of dose response and survival. Radiother. Oncol. 2019, 137, 153-158. [CrossRef]

6. Weissbach, L.; Handlogten, M.E.; Christensen, H.N.; Kilberg, M.S. Evidence for two Na+-independent neutral amino acid transport systems in primary cultures of rat hepatocytes. Time-dependent changes in activity. J. Biol. Chem. 1982, 257, 12006-12011. [CrossRef]

7. Detta, A.; Cruickshank, G.S. 1-Amino Acid Transporter-1 and Boronophenylalanine-Based Boron Neutron Capture Therapy of Human Brain Tumors. Cancer Res. 2009, 69, 2126-2132. [CrossRef] [PubMed]

8. Yoon, J.H.; Kim, I.J.; Kim, H.; Kim, H.-J.; Jeong, M.J.; Ahn, S.G.; Kim, A.S.; Lee, C.H.; Choi, B.K.; Kim, J.-K.; et al. Amino acid transport system $\mathrm{L}$ is differently expressed in human normal oral keratinocytes and human oral cancer cells. Cancer Lett. 2005, 222, 237-245. [CrossRef]

9. Kim, D.K.; Ahn, S.G.; Park, J.C.; Kanai, Y.; Endou, H.; Yoon, J.H. Expression of L-type amino acid transporter 1 (LAT1) and 4F2 heavy chain (4F2hc) in oral squamous cell carcinoma and its precusor lesions. Anticancer. Res. 2004, 24, 1671-1675.

10. Obayashi, S.; Kato, I.; Ono, K.; Masunaga, S.-I.; Suzuki, M.; Nagata, K.; Sakurai, Y.; Yura, Y. Delivery of 10boron to oral squamous cell carcinoma using boronophenylalanine and borocaptate sodium for boron neutron capture therapy. Oral Oncol. 2004, 40, 474-482. [CrossRef]

11. Lin, Y.C.; Wang, S.J.; Chung, H.P.; Liu, H.M.; Chou, F.I. Low dose of gamma irradiation enhanced boronophenylalanine uptake in head and neck carcinoma cells for boron neutron capture therapy. Appl. Radiat. Isot. 2011, 69, 1728-1731. [CrossRef]

12. Wu, C.-Y.; Chan, P.-C.; Chou, L.-S.; Chang, C.-W.; Yang, F.-Y.; Liu, R.-S.; Chiou, S.-H.; Chen, Y.-W.; Yen, S.-H.; Wang, H.-E. Pulsed-Focused Ultrasound Enhances Boron Drug Accumulation in a Human Head and Neck Cancer Xenograft-Bearing Mouse Model. Mol. Imaging Biol. 2013, 16, 95-101. [CrossRef]

13. Yang, W.; Barth, R.F.; Huo, T.; Kabalka, G.W.; Shaikh, A.L.; Haider, S.A.; Chandra, S. Effects of l-DOPA pre-loading on the uptake of boronophenylalanine using the F98 glioma and B16 melanoma models. Appl. Radiat. Isot. 2014, 88, 69-73. [CrossRef]

14. Rosenberg, T.; Wilbrandt, W. Uphill transport induced by counterflow. J. Gen. Physiol. 1957, 41, 289-296. [CrossRef]

15. Heinz, E.; Walsh, P. Exchange Diffusion, Transport, and Intracellular Level of Amino Acids in Ehrlich Carcinoma Cells. J. Biol. Chem. 1958, 233, 1488-1493. [CrossRef]

16. Page, C.M.; Inglis, M.S.; Wheatley, D.N. The intracellular acid-extractable (acid-soluble) amino acid pool in mammalian cells: 4 An hypothesis to explain the effects of preloading on the exchange of amino acids across the cell membrane. Cytobios 1982, 34, 105-123.

17. Wittig, A.; Sauerwein, W.A.; Coderre, J.A. Mechanisms of transport of p-borono-phenylalanine through the cell membrane in vitro. Radiat. Res. 2000, 153, 173-180. 
18. Watanabe, T.; Tanaka, H.; Fukutani, S.; Suzuki, M.; Hiraoka, M.; Ono, K. L-phenylalanine preloading reduces the 10B(n, $\alpha$ )7Li dose to the normal brain by inhibiting the uptake of boronophenylalanine in boron neutron capture therapy for brain tumours. Cancer Lett. 2016, 370, 27-32. [CrossRef]

19. Papaspyrou, M.; Feinendegen, L.E.; Müller-Gärtner, H.W. Preloading with L-tyrosine increases the uptake of boronophenylalanine in mouse melanoma cells. Cancer Res. 1994, 54, 6311-6314.

20. Capuani, S.; Gili, T.; Bozzali, M.; Russo, S.; Porcari, P.; Cametti, C.; D’Amore, E.; Colasanti, M.; Venturini, G.; Maraviglia, B.; et al. L-DOPA Preloading Increases the Uptake of Borophenylalanine in C6 Glioma Rat Model: A New Strategy to Improve BNCT Efficacy. Int. J. Radiat. Oncol. 2008, 72, 562-567. [CrossRef]

21. Heo, D.S.; Snyderman, C.; Gollin, S.M.; Pan, S.; Walker, E.; Deka, R.; Barnes, E.L.; Johnson, J.T.; Herberman, R.B.; Whiteside, T.L. Biology, cytogenetics, and sensitivity to immunological effector cells of new head and neck squamous cell carcinoma lines. Cancer Res. 1989, 49, 5167-5175. [PubMed]

22. Dirix, P.; Nuyts, S.; van der Bogaert, W. Radiation-induced xerostomia in patients with head and neck cancer. Cancer 2006, 107, 2525-2534. [CrossRef]

23. Wang, L.-W.; Chen, Y.-W.; Ho, C.-Y.; Liu, Y.-W.H.; Chou, F.-I.; Liu, Y.-H.; Liu, H.-M.; Peir, J.-J.; Jiang, S.-H.; Chang, C.-W.; et al. Fractionated Boron Neutron Capture Therapy in Locally Recurrent Head and Neck Cancer: A Prospective Phase I/II Trial. Int. J. Radiat. Oncol. 2016, 95, 396-403. [CrossRef]

24. Shotwell, M.A.; Oxender, D.L. The regulation of neutral amino acid transport by amino acid availability in animal cells. Trends Biochem. Sci. 1983, 8, 314-316. [CrossRef]

25. Moreno, A.; Lobatón, C.D.; Oxender, D.L. Regulation of amino acid transport system L by amino acid availability in CHO-K1 cells. A special role for leucine. Biochim. Biophys. Acta Biomembr. 1985, 819, 271-274. [CrossRef]

26. Campbell, W.A.; Thompson, N.L. Overexpression of LAT1/CD98 Light Chain Is Sufficient to Increase System 1-Amino Acid Transport Activity in Mouse Hepatocytes but Not Fibroblasts. J. Biol. Chem. 2001, 276, 16877-16884. [CrossRef]

27. Grunewald, C.; Sauberer, M.; Filip, T.; Wanek, T.; Stanek, J.; Mairinger, S.; Rollet, S.; Kudejova, P.; Langer, O.; Schütz, C.; et al. On the applicability of [18F]FBPA to predict L-BPA concentration after amino acid preloading in HuH-7 liver tumor model and the implication for liver boron neutron capture therapy. Nucl. Med. Biol. 2017, 44, 83-89. [CrossRef]

28. Wingelhofer, B.; Kreis, K.; Mairinger, S.; Muchitsch, V.; Stanek, J.; Wanek, T.; Langer, O.; Kuntner, C. Preloading with L-BPA, L-tyrosine and L-DOPA enhances the uptake of [18F]FBPA in human and mouse tumour cell lines. Appl. Radiat. Isot. 2016, 118, 67-72. [CrossRef] [PubMed]

29. Kreimann, E.L.; Itoiz, M.E.; Dagrosa, A.; Garavaglia, R.; Farías, S.; Batistoni, D.; Schwint, A.E. The hamster cheek pouch as a model of oral cancer for boron neutron capture therapy studies: Selective delivery of boron by boronophenylalanine. Cancer Res. 2001, 61, 8775-8781.

30. Trivillin, V.A.; Garabalino, M.A.; Colombo, L.L.; Gonzalez, S.J.; Farias, R.O.; Monti Hughes, A.; Pozzi, E.C.; Bortolussi, S.; Altieri, S.; Itoiz, M.E.; et al. Biodistribution of the boron carriers boronophenylalanine (BPA) and/or decahydrodecaborate (GB-10) for Boron Neutron Capture Therapy (BNCT) in an experimental model of lung metastases. Appl. Radiat. Isot. 2014, 88, 94-98. [CrossRef]

31. Ring, K.; Gross, W.; Heinz, E. Negative feedback regulation of amino acid transport in Streptomyces hydrogenans. Arch. Biochem. Biophys. 1970, 137, 243-252. [CrossRef] 